\title{
Covid-19: Digital Signature Impact on Higher Education Motivation Performance
}

\author{
Untung Rahardja ${ }^{\mathrm{a}, 1, *}$, Sudaryono ${ }^{\mathrm{a}, 2}$, Nuke Puji Lestari Santoso ${ }^{\mathrm{a}, 3}$, Adam Faturahman ${ }^{\mathrm{a}, 4}$, Qurotul \\ Aini ${ }^{\mathrm{a}, 5}$ \\ ${ }^{a}$ Universitas Raharja, Jl. Jenderal Sudirman No.40, RT.002 / RW.006, Cikokol, Kota Tangerang, Indonesia \\ ${ }^{1}$ untung@raharja.info*; ${ }^{2}$ sudaryono@raharja.info; ${ }^{3}$ nuke@raharja.info; ${ }^{4}$ adam.faturahman@raharja.info; ${ }^{5}$ aini@raharja.info \\ * corresponding author
}

ARTICLE INFO

\begin{abstract}
At present, the process of validating documents for certain purposes cannot be done face-to-face because of the Covid-19 pandemic. Therefore, this research aims to maximize the existence of smart digital signature technology that guarantees its safety and validity without having to meet face to face. Encrypted digital signatures with RSA-SHA256 with cloud storage features that can share documents. The waterfall method for building systems, the collection of data generated for analysis by observation, and online questionnaires using Google Form. Based on the characteristics of the system, the satisfaction factor analysis of the system with the Slovin formula processed by the SUS score resulted in a score of 95 $>70$. The final result of this study is that the digital signature system has a significant impact on increasing motivation to facilitate authorization and secure documents.
\end{abstract}

Article history:

Received 12-05-2020

Revised 01-06-2020

Accepted 05-06-2020

Keywords:

Digital Signature

Cloud Storage

Motivation

Covid-19

Copyright () 2017 International Journal of Artificial Intelegence Research. All rights reserved.

\section{Introduction}

Coronavirus 2019 (Covid-19) is spreading so fast that it has even become a global pandemic affecting developing countries with limited resources [1]. Most developing countries assume that they will face more challenges than developed countries in overcoming the spread of Covid-19 in their regions, which causes developing countries to potentially become the epicenter of a pandemic, including Indonesia [2]. The Covid-19 case in Indonesia on March 2, 2020, has confirmed two Covid-19 cases. Then on March 29, 2020, it continued to increase to 1,285 cases in 30 provinces. According to data from the Ministry of Health of the Republic of Indonesia, five provinces with the highest Covid-19 cases were Jakarta (675), Banten (106), West Java (149), Central Java (63), and East Java (90) [3]. The increasing incidence of such cases and has spread globally, the WHO set Covid-19 as a pandemic [4].

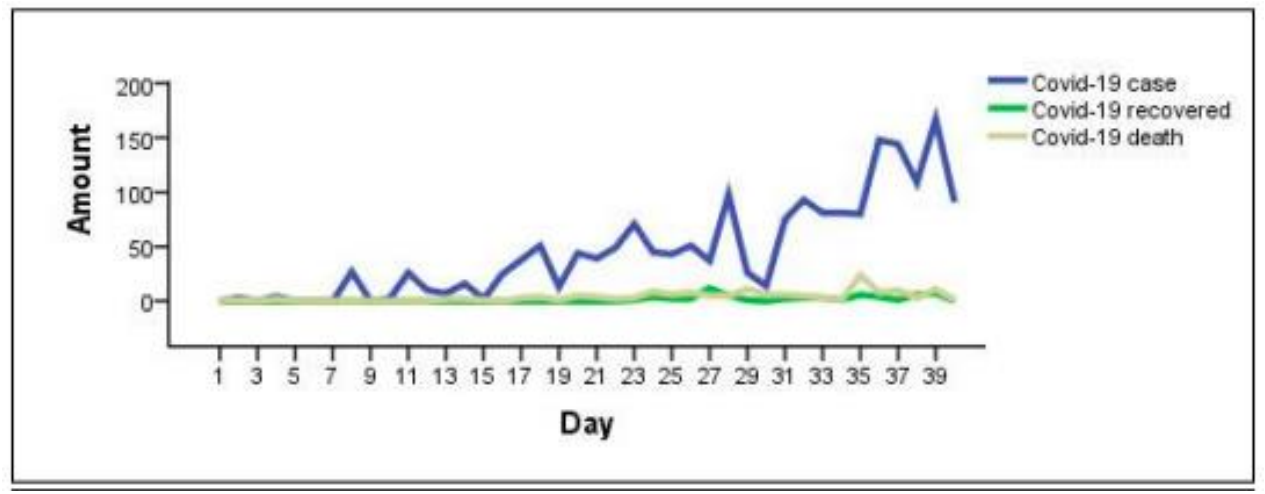


Fig. 1. Covid-19 status

Figure 1 shows the Covid-19 graph of Jakarta that has increased. Since March 3, 2020, cases in Jakarta have averaged 45.25 Covid-19 cases confirmed every day. So the average number of patients who must be recovered is 1.50 , which is lower than the average death rate of 3.80 cases. Thus, the proportion of deaths in Jakarta Covid-19 cases is $8.4 \%$ higher than those cured by 3.3\% [5]. Of the many cases, this has made several companies to higher education affected in terms of economics, social activities, and management [6]. This pandemic Covid-19 has a significant impact on the world cycle of higher education in terms of staff performance. Industry 4.0 is the era of smart systems that are used for flexible production lines throughout the information, for example, created by the Internet of Things (IoT), Artificial Intelligence (AI), or other digital technologies [7][8]. Transformation era 4.0 on a particular website is in line with what is needed to face the problem [9][10]. This pandemic situation allows for the innovative use of technology that can bridge the education gap during this Covid-19 [11][12].

This incident did not rule out the possibility of technology playing a role in the management of this pandemic Covid-19 to help not only in terms of health but the technology industry 4.0 virtually [13][14]. One solution that will be discussed in this paper is the use of digital signatures with SHA256 as a form of Work From Home (WFH) support in this pandemic Covid-19 with the aim of activities of the academic community of higher education to continue to run effectively. Digital signatures are an essential type of authentication on public keys in widely used cryptography [15] by using public and private keys to encrypt and decrypt [16]. Utilization of cloud storage is at war also crucial in the cloud ecosystem, where now many are using cloud storage because it can be considered significant data integrity [17].

\section{Method}

In making digital signature systems using the SDLC waterfall method by using the waterfall model, all processes are divided into several stages, and this certainly makes the process of making the system very clear so that it can produce an effective and efficient system when there is a Covid19 pandemic [18][19]. In the illustration in Figure 1 of the seven stages of SDLC Waterfall, the process of making the system begins with a systematic analysis of the needs of tertiary education invalidating important documents, followed by the process of sending documents to the procedure for storing copies of documents after all authorizations are analyzed which will produce a plan to make the system as needed. From the plans that have been made, there will emerge a lower need for the system to be designed such as embedding features of a digital signature system with SHA-256 encryption, making a cloud storage design so that authentic documents can be stored on the internet and can be accessed by anyone without having to send mail by manual means, as well as the design in terms of security where documents are protected with irreversible protection[20][21][22].

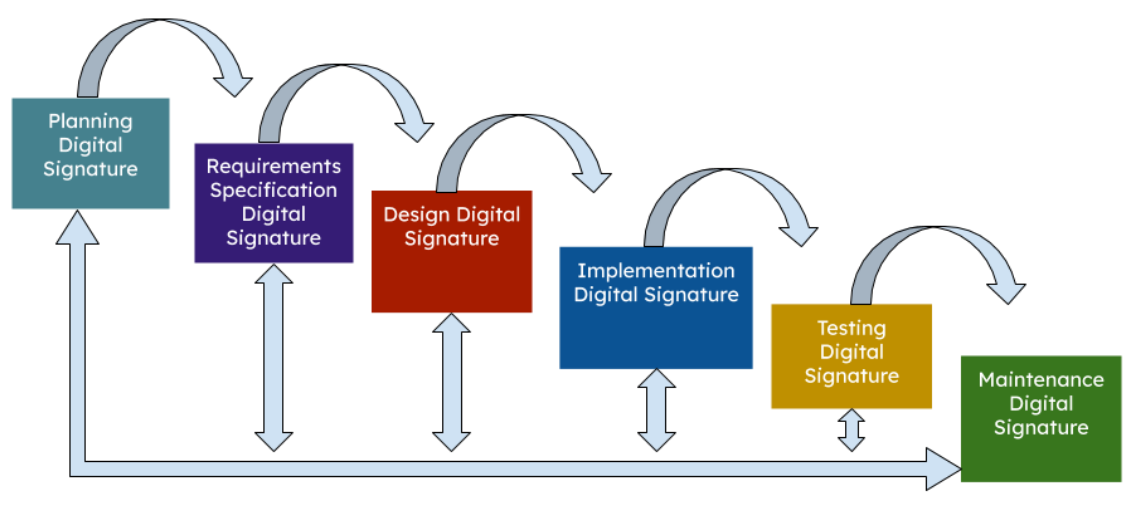

Fig. 2.Methods of Waterfall Digital Signature System

After we know about the needs that must be made next is to develop the design into a digital signature system design, starting from the user interface design, user experience so that it can 
produce a user-friendly experience for users, design data structures that support cloud storage and digital signatures[23][24]. The design of programming algorithms for document encryption, automatically generating pdfs, document sharing features, sending documents via email, to irreversible security features. Next design is the process of implementing the design into the PHP programming language with the MVC concept to meet the needs of the backend in processing algorithms and high security, as well as for the database part of researchers using PostgreSQL, followed by the frontend using Javascript, HTML, Bootstrap CSS[25][26]. After the system has been successfully built, a testing phase is needed to find out if the system is running as planned, at this stage the system is released to the user to get feedback so that further development can be done. Moreover, the last is the maintenance stage, where at this stage, researchers respond to user feedback by making improvements and additions according to what they expect [27][28][29].

After the system has been released and tested by some users, the researcher then evaluates the digital signature system. It starts with gathering information about the number of staff in higher education[30]. To support Work From Home activities due to Covid-19, this research collects data by survey method in the form of an online questionnaire using Google Form. Followed by finding the number of samples of staff population information from the population data that can be, the total staff population currently reaches 148 people, the next stage of the data we will manage again to find out the number of samples that are appropriate for SUS. If calculated using the Slovin formula[31].

$$
n=\frac{N}{1+N e^{2}}
$$

Where $\mathrm{n}$ is the total number of samples sought, $\mathrm{N}=$ number of general population, $\mathrm{e}=$ error tolerance limit.

From the calculations that have been done, we get the right number of staff samples, the next step of the data will be used to find the SUS (System Usability Scale) so that researchers know how well the system is implemented. System Usability Scale (SUS) is a self-administered statement instrument that is often used to evaluate its usefulness in terms of product and user interface [36]. The following formula looks for the overall value of SUS:

$$
X=\frac{(((R 1)+(R 2)+(R 3)+(R 4)+(R 5)+(R 6)+(R 7)+(R 8)+(R 9)+(R 10)) * 2,5) * N}{N}
$$

$\mathrm{X}$ is the total SUS score, where $\mathrm{N}$ is the number of staff, and R1 to R10 is the respondent's statement variable from the whole questionnaire given. At the evaluation stage, researchers used the SUS questionnaire with a five-point Likert scale. Start from the respondent, the staff was asked to provide a subjective assessment of the Digital Signature system of the ten-question items with statements between "Strongly disagree," "Disagree," "Neutral," "Agree," and "Strongly Agree," which respectively -The answer of each item is variable R1 to R10. When Covid-19, the questionnaire was distributed to all samples, namely the staff of the University of Raharja, through Google's online form. Finally, the respondents will state so that the results of the overall SUS Score will be obtained based on the acquisition of the average individual SUS score[32].

\section{Result}

After getting information about the staff population at the college. Researchers performed calculations using the Slovin formula. The initial step taken was to enter the staff population into the variable $\mathrm{N}=148$, and the error tolerance limit of $1 \%$, so that the required number of staff samples was as follows: 


$$
\begin{gathered}
n=\frac{148}{1+148 \cdot(0,01)^{2}} \\
n=\frac{148}{2,48} \\
n=59,67 \rightarrow 60
\end{gathered}
$$

After knowing the exact number of samples, the SUS questionnaire in the form of an online google form was given to staff respondents, and the respondents gave statements with values based on a Likert scale. Moreover, the results of the respondent's statement are included in the Likert scale table, which will later be used as a variable in the SUS formula.

\section{Digital Signature}

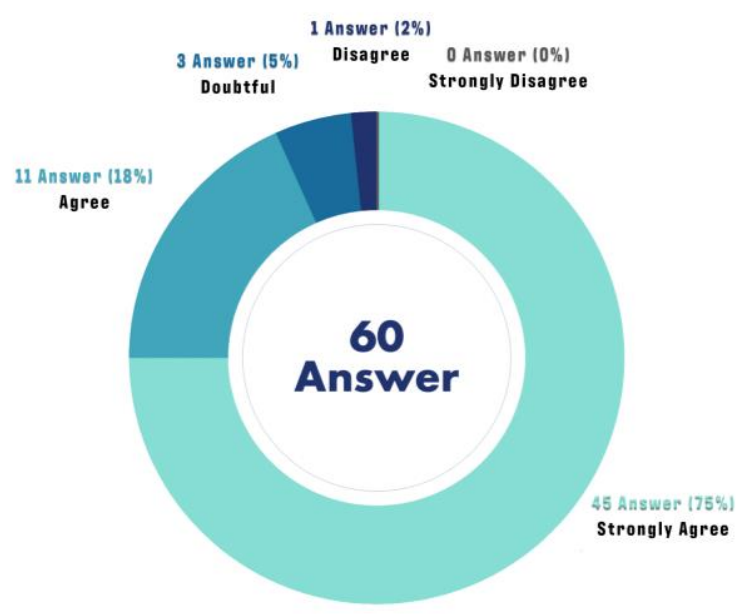

Fig. 3.Likert scale respondent results

Based on the Doughnut chart on figure 3,75\% of staff respondents gave statements with a 5 point Likert scale, $18 \%$ with 4 points, $5 \%$ with 3 points, and $2 \%$ with 2 points. From the information we get, we enter into the R1-R10 variable to find out the total SUS:

$$
\begin{gathered}
X=\frac{(((R 1)+(R 2)+(R 3)+(R 4)+(R 5)+(R 6)+(R 7)+(R 8)+(R 9)+(R 10)) * 2,5) * N}{N} \\
X=\frac{((5)+(5)+(2)+(3)+(3)+(4)+(4)+(5)+(5)+(5)) * 2,5) * 60}{60} \\
X=\frac{5700}{60}=95,0
\end{gathered}
$$

From the questionnaire distributed to the entire population, they are then calculating using the SUS Suspension formula, resulting in $X$ as the SUS score. The results determine that the average SUS staff score was 95.0, which SUS score is a global subjective assessment of the aspects of usability like efficient, effective, and user satisfaction with the system used.

Table 1. SUS digital signature score categories

\begin{tabular}{ccc}
\hline Category & Requirement & Result \\
\hline Not Acceptable & $<50$ & $\mathbf{x}$ \\
\hline Acceptable & $>70$ & $\checkmark$ \\
\hline Net Promoter & $>82$ & $\checkmark$ \\
\hline Detractor & $<67$ & $\mathbf{x}$ \\
\hline
\end{tabular}

SUS score will indicate the level of user satisfaction with the system if the SUS score achieved > 70 and can be said to be in the Acceptable category [37]. 
DIGITAL SIGNATURE SUS

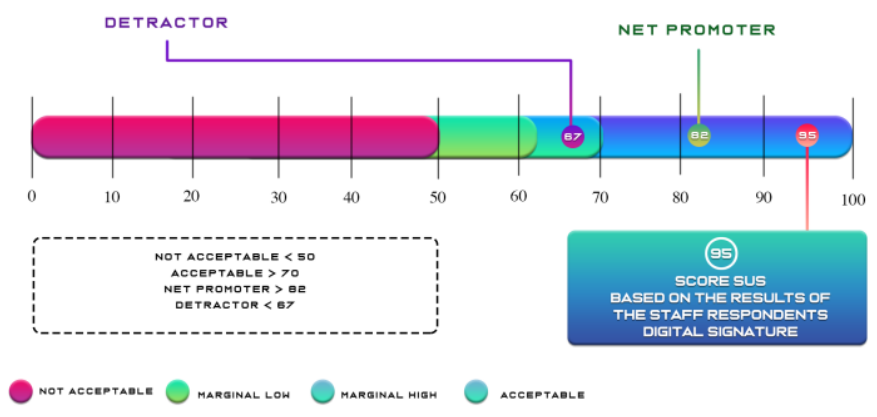

Fig. 4.SUS Digital Signature score results

The results of the figure 4 calculation we can get a digital signature system SUS score of 95.0, this can be stated that the system falls into the Acceptable category. Then there is a requirement that the system can be called a Net Promoter if the SUS score reaches $>82$, And this also shows that the digital signature system has the potential to be a promoter so that the impact on the number of users will continue to increase during the Covid-19 pandemic. As for the detractor category, it means that it can cause a significant reduction; this does not affect the digital signature system because the score exceeds $>67$ [33]. The final results of the SUS score table above show the acquisition of a positive and significant impact on the system created because the number of users will continue to increase in the future. After all, it has benefits in the pandemic Covid-19 period [34]. The results of this survey are also a motivation for higher education to continue to carry out academic activities in the Covid-19 pandemic [35][36].

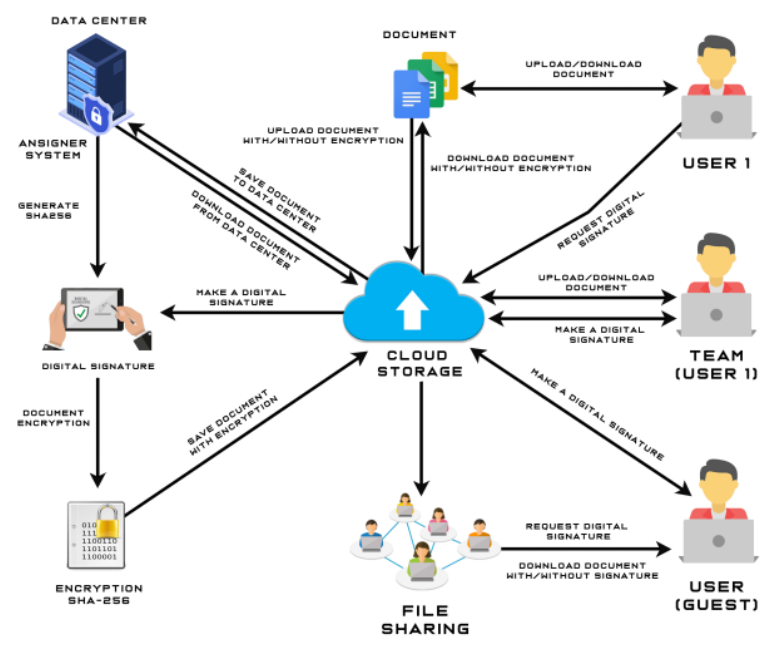

Fig. 5. Signature Cloud Storage Digital Architecture

The picture figure 5 is the workflow of the Digital Signature system, and User 1 has the right to download and upload documents into the system, both encrypted and unencrypted. The document that has been uploaded can be entered into the cloud storage service, where all files that have entered or exited will enter the data center so that it can be monitored by the system so that it is well distributed. This system implements SHA-256 encryption for digital signatures so that each document that has been signed has a unique document identity wherein the data encryption process regarding who signs, the time of authorization, and also about the location and IP address will be entered. Every document that has been embedded with encryption will be irreversible, which means the document cannot be modified after it is signed. This is useful to avoid falsification of documents and other crimes. After the encryption stage is completed, the signed documents will be stored in cloud storage integrated with the data center within the AN Signer system. 
For other users such as team members or users outside the system or guests can receive messages in the form of documents that have been signed through the Digital Signature system by utilizing the file-sharing feature, this certainly makes it easy for users to send important documents without having to print or conduct meetings to facilitate work when the Covid-19 pandemic. Every user has the right to sign documents. User 1, who has registered with the system, can, of course, make a signature request to anyone by utilizing file-sharing by only sending documents via email so the digital signature process can be easily carried out during the Covid-19 pandemic [37] Signed documents can be stored by the intended party and also stored in cloud storage.

\section{Conclusion}

In this study, SHA-256 is applied as an encryption system embedded in a digital signature for authorization, verification of validity \& protecting documents to avoid crime such as modification and so because it is irreversible, which means it cannot be returned to its original form. Besides, the cloud storage feature was added to support the Covid-19 period in storing documents that already have digital signatures to make it more secure and for ease of sharing documents with other users. From the results of the analysis using the SUS score shows that the digital signature system is in the Acceptable category with a score of $95>70$ to help the Covid-19 period.

In the results of the above study, the Covid-19 pandemic did not allow for a meeting, but there was an important document that required authorization to make tertiary education management difficult in that regard. With a website based digital signature system that supports cloud storage services for document sharing with ease of accessibility for users and can validate documents securely using an encrypted digital signature when Covid-19. When this digital signature system is considered easy to use, the implication is that the head of staff of higher education will use this application to support the academic performance of the Covid-19 period is an important document.

It is hoped that future work digital signatures can be developed with more sophisticated security technology, namely the blockchain so that future researchers can have a significant impact on subsequent papers.

\section{Acknowledgment}

his research is fully supported by the University of Raharja to examine the digital signature system during the Covid-19 pandemic, such as online data collection and case studies. Moreover, thank Alphabet Incubator for a significant and useful discussion on this research.

\section{References}

[1] T. Singhal, “A Review of Coronavirus Disease-2019 (COVID-19)",, Indian J. Pediatr., vol. 87, no. 4, pp. 281286 ,

[2] J. Hopman, B. Allegranzi, and S. Mehtar, "Managing COVID-19 in Low- and Middle-Income Countries"," $J A M A$, vol. 323 , no. 16 , p. 1549.

[3] K. K. R. Indonesia, "Pedoman Pencegahan dan Pengendalian Corona Virus Diaseases.” p. 19.

[4] E. Mahase, "Covid-19: WHO declares pandemic because of 'alarming levels' of spread, severity, and inaction"," $B M J$, p. 1036.

[5] A. Asyary and M. Veruswati, "Sunlight exposure increased Covid-19 recovery rates: A study in the central pandemic area of Indonesia"," Sci. Total Environ., vol. 729, p. 139016.

[6] T. Hariguna, U. Rahardja, Q. Aini, and Nurfaizah, "Effect of social media activities to determinants public participate intention of e-government," Procedia Comput. Sci, vol. 161, pp. 233-241, doi: 10.1016/j.procs.2019.11.119.

[7] A. Haleem, M. Javaid, and R. Vaishya, "Industry 4.0 and its applications in orthopaedics"," J. Clin. Orthop. Trauma, vol. 10, no. 3, pp. 615-616,

[8] Y. Liao, F. Deschamps, E. Loures, and L. Ramos, "Past, present and future of Industry 4.0 - a systematic 
literature review and research agenda proposal"," Int. J. Prod. Res., vol. 55, no. 12, pp. 3609-3629,.

[9] U. R. Sudaryono and E. P. Harahap, "Implementation of Information Planning and Strategies Industrial Technology 4.0 to Improve Business Intelligence Performance on Official Site APTISI," J. Phys. Conf. Ser, vol. 1179, no. 1, pp. 0-7, doi: 10.1088/1742-6596/1179/1/012111.

[10] Q. Aini, N. Lutfiani, F. Hanafi, and U. Rahardja, "Application of Blockchain Technology for iLearning Student Assessment,” IJCCS (Indonesian J. Comput. Cybern. Syst, vol. 14, no. 2, doi: 10.22146/ijccs.53109.

[11] R. Chick, "Using Technology to Maintain the Education of Residents During the COVID-19 Pandemic"," J. Surg. Educ.

[12] Q. Aini, U. Rahardja, and A. Khoirunisa, "Blockchain Technology into Gamification on Education," IJCCS (Indonesian J. Comput. Cybern. Syst, vol. 14, no. 2, pp. 1-10, doi: 10.22146/ijccs.53221.

[13] M. Javaid, A. Haleem, R. Vaishya, S. Bahl, R. Suman, and A. Vaish, "Industry 4.0 technologies and their applications in fighting COVID-19 pandemic"," Diabetes Metab. Syndr. Clin. Res. Rev., vol. 14, no. 4, pp. 419422 .

[14] U. Rahardja, Q. Aini, Y. I. Graha, and M. R. Tangkaw, "Gamification Framework Design of Management Education and Development in Industrial Revolution 4.0," J. Phys. Conf. Ser, vol. 1364, no. 1, pp. 0-13, doi: 10.1088/1742-6596/1364/1/012035.

[15] W. Stallings, Cryptography and network security: principles and practice, 4th ed.Englewood. Cliffs, NJ: Prentice-Hall.

[16] Z. Sann, T. Soe, K. Knin, and Z. Win, "Performance Comparison of Asymmetric Cryptography (Case studyMail message)"," АРTIKOM J. Comput. Sci. Inf. Technol., vol. 4, no. 3, pp. 105-111,.

[17] H. Wang, H. Qin, M. Zhao, X. Wei, H. Shen, and W. Susilo, "Blockchain-based fair payment smart contract for public cloud storage auditing"," Inf. Sci. (Ny)., vol. 519, pp. 348-362,.

[18] J. Chen, H. Zhang, X. Zhou, C. Zhang, and Q. Wang, "Practical decoy-state quantum digital signature with optimized parameters"," Phys. A Stat. Mech. its Appl., vol. 535, p. 122341.

[19] E. Martiri and A. Baxhaku, "Monotone digital signatures: an application in software copy protection"," Procedia Technol., vol. 1, pp. 275-279,.

[20] N. Tiwari, "On the security of pairing-free certificateless digital signature schemes using ECC"," ICT Express, vol. 1, no. 2, pp. 94-95,

[21] H. S. V. Bralić and M. Stengård, "A blockchain approach to digital archiving: digital signature certification chain preservation"," Rec. Manag. J.

[22] M. Zhao et al., "H2Cloud"," in Proceedings of the 47th International Conference on Parallel Processing - ICPP 2018, doi: 10.1145/3225058.3225083).

[23] T. Alam, "Cloud Computing and its role in the Information Technology"," IAIC Trans. Sustain. Digit. Innov. (ITSDI, vol. 1, no. 2, pp. 108-115,

[24] D. M. and M. K, "Implementing Multiprime RSA Algorithm to Enhance the Data Security in Federated Cloud Computing"," IJARCCE, vol. 4, no. 4, pp. 647-650,.

[25] D. Piparo, E. Tejedor, P. Mato, L. Mascetti, J. Moscicki, and M. Lamanna, "SWAN: A service for interactive analysis in the cloud"," Futur. Gener. Comput. Syst., vol. 78, pp. 1071-1078,.

[26] J. James, R. Karthika, and R. Nandakumar, "Design \& Characterization of SHA 3- 256 Bit IP Core"," Procedia Technol., vol. 24, pp. 918-924,. 
[27] H. Michail, G. Athanasiou, G. Theodoridis, A. Gregoriades, and C. Goutis, "Design and implementation of totally-self checking SHA-1 and SHA-256 hash functions' architectures"," Microprocess. Microsyst., vol. 45, pp. 227-240,

[28] I. Algredo-Badillo, C. Feregrino-Uribe, R. Cumplido, and M. Morales-Sandoval, "FPGA-based implementation alternatives for the inner loop of the Secure Hash Algorithm SHA-256"," Microprocess. Microsyst., vol. 37, no. 6-7, pp. 750-757,

[29] U. Somani, K. Lakhani, and M. Mundra, "Implementing digital signature with RSA encryption algorithm to enhance the Data Security of cloud in Cloud Computing"," in First International Conference On Parallel, Distributed and Grid Computing (PDGC 2010.

[30] E. Febriyanto, U. Rahardja, A. Faturahman, and N. Lutfiani, "Sistem Verifikasi Sertifikat Menggunakan Qrcode pada Central Event Information"," Techno.Com, vol. 18, no. 1, pp. 50-63,.

[31] A. Khalique, K. Singh, and S. Sood, "Implementation of Elliptic Curve Digital Signature Algorithm"," Int. J. Comput. Appl., vol. 2, no. 2, pp. 21-27,.

[32] M. Kumar and K. Asiwal, "Use of Digital Signature Standard with Station to Station Key Exchange Agreement and Cloud Manager to Enhance Security in Cloud Computing"," Int. J. Appl. Inf. Syst., vol. 7, no. 8, pp. 1-5,.

[33] A. Sinaga, "The Comparison of Signature Verification Result Using 2DPCA Method and SSE Method"," Int. J. Artif. Intell. Res., vol. 2, no. 1, p. 14.

[34] M. Sathiyanarayanan and T. Mulling, "Map Navigation Using Hand Gesture Recognition: A Case Study Using MYO Connector on Apple Maps"," Procedia Comput. Sci., vol. 58, pp. 50-57,.

[35] U. Rahardja, A. Moeins, and N. Lutfiani, "Leadership, competency, working motivation and performance of high private education lecturer with institution accreditation B: Area kopertis IV Banten province," Man India, vol. 97, no. 24, pp. 179-192,

[36] J. Leonard, D. Damanik, and O. Amirkhasanah, "APPLICATION OF INFORMATION SESSION INFORMATION SYSTEM AS MEDIA SUBMISSION OF FINAL RESULTS COMPREHENSIVE SESSION"," ADI J. Recent Innov. (AJRI, vol. 1, no. 1, pp. 62-70,.

[37] T. Hidayat and R. Mahardiko, "A Systematic Literature Review Method On AES Algorithm for Data Sharing Encryption On Cloud Computing"," Int. J. Artif. Intell. Res., vol. 4, no. 1. 